https://doi.org/10.18485/iipe_postkovid.2021.ch7

\title{
NORMATIVNA MOĆ KAO ASPEKT SPOLNE POLITIKE EVROPSKE UNIJE U KONTEKSTU PANDEMIJE KOVID 19
}

\begin{abstract}
Nevena STANKOVIĆ ${ }^{1}$
Apstrakt: Izbijanje pandemije Kovid 19 predstavlja poslednji u nizu izazova sa kojima se Evropska unija (EU) suočila u protekloj deceniji, dovodeći ponovo u pitanje projekat evropskih integracija, kako iznutra tako i spolja. Ispostavilo se da, uprkos međunarodnom prisustvu, EU ne može da deluje jedinstveno na globalnoj sceni, što je delom uzrokovano pravilom jednoglasnog glasanja u oblasti njene spoljne politike. Početni nedostatak unutrašnje solidarnosti i kordinacije unutar njenih država članica, diskvalifikovali su Uniju kao kredibilnog geopolitičkog aktera koji je u stanju da pouzdano odgovori na krizu.

Sa druge strane, trajanje pandemije pružilo je Uniji priliku da konačno oblikuje geopolitički profil i ojača svoj položaj u svetu koji se menja. U tom kontekstu, pandemija je stvorila zahtev za bližom multilateralnom saradnjom. Združeni faktori poput američko-kineskog rivalstva, evropskog odgovora na pandemiju, kao i potrebe za globalnom saradnjom otvorili su put ponovnom evropskom pokretanju multilateralizma. Kombinacija fenomena pandemije i rasta evropskog uticaja preusmerili su Uniju u pravcu uvećanja normativnog uticaja na međunarodnom i regionalnom nivou.

U radu se polazi od hipoteze da EU treba da iskoristi svoju normativnu moć kako bi poboljšala geopolitički položaj, postajući time treći pol uticaja između SAD i Kine. Pored unutrašnje kohezije, EU bi trebalo da promoviše dinamičnu i autonomnu spoljnu politiku zasnovanu na svom normativnom identitetu. Jačanje normativne snage zahteva od EU najpre jačanje normativnih instrumenata, poput regionalnih i strateških partnerstava, uz istovremenu težnju ka evropskoj strateškoj autonomiji.
\end{abstract}

\footnotetext{
${ }^{1}$ Naučni saradnik u Institutu za međunarodnu politiku i privredu, Beograd. E-mail: nevena@diplomacy.bg.ac.rs

Rad je nastao u okviru naučnoistraživačkog projekta „Srbija i izazovi u međunarodnim odnosima 2021. godine" koji finansira Ministarstvo prosvete, nauke i tehnološkog razvoja Republike Srbije, a realizuje Institut za međunarodnu politiku i privredu tokom 2021. godine.
} 
Analizirajući postojeće nedostatke, ali i nove mogućnosti u spoljnopolitičkom pristupu EU koji se oslanja na novi multilateralizam, rad ispituje i mogućnosti buduće saradnje Unije sa ostatkom sveta u svetlu novih izazova koji su se pojavili usled pandemije Kovid 19.

Ključne reči: EU, pandemija, Kovid 19, multilateralizam, spoljna politika, normativna moć.

\section{Uvod}

Globalna zdravstvena kriza, nastala usled izbijanja pandemije Kovid 19, nesumnjivo je predstavila veliki izazov za celokupni međunarodni sistem. Čini se da je već od momenta izbijanja pandemija nametnula intenzivnu konkurenciju između globalnih igrača, stavivši u fokus i dalje aktuelno pitanje pouzdanog međunarodnog partnera u borbi protiv korona virusa i posledica koje on proizvodi.

Pandemija predstavlja poslednji u nizu egzistencijalnih izazova i za Evropsku uniju, budući da je ogolila samo neke od problema koji je potresaju godinama unazad, dovodeći ponovo u pitanje njen sistem upravljanja. O ovome svedoči i mišljenje dela doktrine da će upravo političke i socijalno-ekonomske posledice drastičnih mera koje su države članice preduzele u svom odgovoru na pandemiju, uticati kako na poverenje građana u nacionalne vlade tako i na stepen u kome će se građani ubuduće identifikovati sa projektom evropskih integracija. ${ }^{2} \mathrm{U}$ tom kontekstu od EU se očekuje da pokaže dodatni kapacitet u suočavanju sa "centrifugalnim“ pristupima država članica, koji su se tokom proteklog perioda mogli čuti iz evropskih prestonica. Istovremeno, težina situacije u kojoj se Unija zatekla mogla bi pak da posluži kao katalizator za ubrzanu integraciju, u smislu jače koordinacije i bržeg i odlučnijeg delovanja na nivou evrozone.

Veći deo stručne javnosti zastupa mišljenje da je sumorna slika koju su stvorili prvobitni pojedinačni odgovori država članica na krizu, razotkrila snažnu potrebu EU da nadoknadi ono što joj je najpotrebnije - unutrašnju solidarnost i jasnije artikulisan, usaglašen pristup. S obzirom na dimenzije problema i stepen društvenog rizika, čini se opravdanim stanovište da je evropski odgovor na krizu

\footnotetext{
${ }^{2}$ Tommaso Emiliani, "How Relevant? The EU's 'Geopolitical' Commission and the Response to the Covid-19 Pandemic", CEPOB - College of Europe Policy Brief, Bruges, No. 4, April 2020. pp. 1-2.
} 
u duhu solidarnosti, imperativ koji nijedna država članica ne bi smela ubuduće da zaobiđe. Imajući u vidu globalni karakter krize, utisak je da bi svaka dalja pojedinačna akcija učinila postupke na nadnacionalnom nivou neefikasnim, što je i bio slučaj u prvoj fazi izbijanja pandemije unutar EU. ${ }^{3}$

Sa druge strane, pandemija je pokazala da drugi geopolitički akteri poput $S A D$, Rusije i Kine poseduju prepoznatljivu kontrolu nad prostorom i resursima unutar svojih granica. Ispostavilo se da ova tri aktera pokazuju relativno visok nivo unutrašnje kohezije i političkog jedinstva, oblikujući svoj identitet uz centralizovano i brzo donošenje odluka. Uprkos činjenici da se radi o transnacionalnoj pretnji, velike sile nisu odlučile da sarađuju putem postojećih međunarodnih mehanizama, već su se okrenule jednostranoj politici. To je dovelo do ishoda da ubrzo nakon izbijanja pandemije, među supersilama započne tzv. trka za vakcinama, dok su njihovi politički lideri iskoristili pandemiju za inauguraciju daljih podela u međunarodnom poretku.

Ova činjenica govori u prilog tvrdnji da je pandemija Kovid 19 samo potvrdila narativ urušenog multilaterarnog sistema, koji se nakon decenija intenzivne globalizacije i integracije suočio sa ozbiljnom krizom. U kontekstu toga, upravo bi Evropska unija mogla imati najrealnije šanse za ključnu ulogu u promociji i negovanju međunarodne saradnje u borbi protiv virusa i njegovih posledica. Popunjavajući „,vakuum“ stvoren američko-kineskim rivalstvom, EU bi mogla da pokaže stručnost u ovom domenu namećući sebe kao nosioca "novog“ multilateralizma. Oživljavajući multilateralizam, kao okosnicu svoje spoljne politike, ključni resurs na koji se EU može osloniti je normativna moć. Stavljanjem svojih normi, ideja i vrednosti u epicentar novog međunarodnog poretka, EU je stanju da povrati poverenje u ideju evropskog projekta, pozicionirajući sebe kao kredibilnog međunarodnog aktera u postpandemijskom svetu.

\section{Ograničenja spoljnopolitičkog pristupa EU u kontekstu pandemije Kovid 19}

Pandemija Kovid 19 otkrila je kako lokalna pitanja mogu postati globalna kriza u okviru koje su zajednički napori, prekogranična saradnja i globalna rešenja

\footnotetext{
${ }^{3}$ Hakan Yapar, "Solidarity within the Union in the face of Covid-19: affirmation or shattering of hopes for EU's Relevance", Bahcesehir University The TEPSA Student Contest 2020, Department of Political Science and International Relations, April 5, 2020, pp. 2-3.
} 
neophodni. lako je početni odgovor na izbijanje pandemije pokazao da je prvi refleks zemalja EU nacionalno orijentisan, uz akcenat na zaštitu sopstvene populacije, ispostavilo se da nacionalni odgovori zahtevaju ipak koordinaciju na evropskom nivou, radi postizanja veće efikasnosti. Relativno sporo koordinisani odgovor EU i često neprofesionalni odnosi sa javnošću, doprineli su slici slabe Evrope u prvoj fazi izbijanja pandemije. lako se stekao prvobitni utisak da je EU u ovoj borbi samu sebe diskvalifikovala, deo autora ipak predviđa da će oblasti poput naučnotehničke saradnje, naučne diplomatije i međunarodne saradnje uopšte, tokom trajanja pandemije naknadno plasirati ulogu Unije. ${ }^{4}$

Sa druge strane, uprkos pozitivnim ocenama na račun kineskog pristupa u suzbijanju pandemije, u javnom diskursu je prisutno sve više kritika usmerenih prvenstveno na nedostatak kineske transparentnosti, ali i na moguće razloge neposrednog izbijanja pandemije. Kako su Sjedinjene Američke Države više okrenute unutrašnjim problemima i izazovima, a Rusija angažovana u otklanjaju posledica pandemije, trenutna konstelacija snaga daje priliku Evropskoj uniji da se nametne kao globalni akter. Ocenjujući uticaj pandemije na buduću spoljnu politiku EU, pojedini autori smatraju da EU treba da iskoristi momenat pada američkog globalnog vođstva za sopstvenu odgovornost i da „preuzme baklju“, prihvatajući ključnu odgovornost u promociji međunarodne saradnje. ${ }^{5}$ Budući da su dijalog, multilateralizam i kompromis kamen temeljac Evropske unije, kao dobitnik Nobelove nagrade za mir iz 2012. godine, Unija uživa poseban legitimitet i kredibilitet kada stupa u kontakt sa partnerima širom sveta, u nastojanju da održi međunarodni sistem uspostavljen nakon Drugog svetskog rata.

lako je još uvek nepoznato da li će ova kriza ostaviti trajni efekat na proces evropskih integracija, poželjno je osvrnuti se na teoriju „,integracije kroz krizu“, koju je u najsavremenijem obliku predstavio Frank Šimelfening (Frank Schimmelfennig), primetivši da krize mogu dovesti do dubljih reformi, u slučajevima kada nadnacionalne institucije imaju dovoljno kapaciteta da

\footnotetext{
${ }^{4}$ Philipp Brugner, Klaus Schuch, "The EU's global response to the COVID-19 crisis with a focus on the Eastern Neighbourhood and Africa", Österreichische Gesellschaft für Europapolitik, ÖGfE Policy Brief, No.13, Vienna, 2020, p. 2.

${ }^{5}$ Hava YURTTAGÜL, "The power of EU soft law: EU's global leadership in promoting multilateralism through soft law", Geopolitics \& Values: what is the real power of the EU?, Institute of European Democrats, Brussels, December 2020. p. 6.
} 
podstaknu promene. ${ }^{6} \mathrm{U}$ pogledu globalnog delovanja EU za vreme i nakon pandemije Kovid 19, od velike je važnosti da građani Unije, ali i trećih država, prepoznaju Uniju kao međunarodnog igrača, posebno na polju ljudskih prava, čija bi efikasna zaštita mogla dovesti do povećanja njenog međunarodnog autoriteta. S druge strane, odlaganje uvođenja pojedinih aktova, poput Akcionog plana za ljudska prava i demokratiju i ograničavanje troškova spoljnopolitičkih inicijativa u novom Višegodišnjem finansijskom okviru, ometaju spoljne napore Unije što može voditi delegitimizaciji njenih akcija kako unutar tako i izvan nje. ${ }^{7}$

Ističiću u svom obraćanju da se Evropljani moraju nositi sa svetom kakav jeste, a ne kakav bi oni želeli da bude, Visoki predstavnik EU za spoljne poslove i bezbednosnu politiku (VP) Žozep Borelj (Josep Borrell), u februaru 2020. godine naglasio je potrebu „ponovnog učenja jezika moći i kombinovanja resursa Evropske unije na način koji uvećava njen geopolitički uticaj". $\mathrm{U}$ vezi s tim su i njegova upozorenja na pojavu tzv. globalne bitke, narativa u kojoj je vreme označeno kao presudni faktor. Ove reči su usledile nekoliko dana nakon što je Rusija u Italiji pokrenula snažnu diplomatsku kampanju u okviru pomoći regionima pogođenim pandemijom Kovid 19.

Sa druge strane, svesna činjenice da EU nije tradicionalni geopolitički akter, predsednica Evropske komisije Ursula von der Lejen (Ursula Gertrud von der Leyen), još u decembru 2019. godine istakla je nove političke prioritete koji definišu geopolitički pristup njene Komisije, dok je pandemija stvorila osnovu za ubrzanje ovakvog trenda. ${ }^{9} \mathrm{U}$ vezi $\mathrm{s}$ tim, njen fokus na jačanju unutrašnje kohezije, izgradnji strateške autonomije i prenosu multilateralne uprave kroz nove strateške saveze, imao je za cilj smanjenje jaza između Unije i drugih velikih

\footnotetext{
${ }^{6}$ Mikolaj Jerzy Bronert, "CAN THE COVID CRISIS LEAD TO LEGITIMIZATION OF EUROPEAN UNION'S FOREIGN POLICIES? Lessons from Belarus", Geopolitics \& Values: what is the real power of the EU, Institute of European Democrats, Brussels, December 2020. pp. 5-6.

${ }^{7}$ Ibid., p. 14-15.

${ }^{8}$ Josep Borrell, Embracing Europe's Power, Project Syndicate, Internet: https://www.projectsyndicate.org/commentary/embracing-europe-s-power-by-josep-borrell-202002? barrier=accesspaylog, 11/04/2021.

${ }^{9}$ Detaljnije o programu EK videti: Ursula Von der Leyen, "Speech by President-elect von der Leyen in the European Parliament Plenary on the occasion of the presentation of her College of Commissioners and their programme", European Commission, 2019, Internet: Speech by President-elect von der Leyen in the EP (europa.eu) 11/04/2021.
} 
sila na globalnoj sceni. ${ }^{10} \mathrm{U}$ trenutnom spoljnopolitičkom pristupu EU, u kom se mešaju geopolitičke ambicije i instrumenti strateške komunikacije, uočavaju se četiri važna ograničenja. Kao prvo, trenutna politika EU označava dezinformacije kao spoljnu pretnju, prikrivajući tako način na koji ih domaći akteri zapravo neguju unutar samih granica EU. Druga se odnosi na agresivnu proveru činjenica koja se sprovodi na institucionalnom nivou, što ugrožava normativnost EU. Treće, fokus na "razmeni poruka" zapravo dovodi do toga da EU na treće aktere gleda kao na pasivne primaoce, zanemarujući ulogu praksi „slušanja“ u cilju interakcije sa stranom publikom. Četvrto, uprkos geopolitičkom zaokretu, nastup EU ostaje u velikoj meri evrocentričan i ugrožava međunarodnu saradnju, posebno u postkolonijalnoj stvarnosti koja na angažovanje EU gleda sa povećanim skepticizmom. ${ }^{11}$ Spora i necentralizovana moć odlučivanja EU raširena je na države članice koje vode žestoke rasprave u Evropskom savetu i Komisiji. Takođe, Unija ne poseduje resurse i mogućnosti uporedive sa kapacitetima relevantnih geopolitičkih igrača, budući da njen budžet iznosi samo oko 1\% BDP-a EU, a njeno delovanje ograničava kontrola država članica nad strateškim oblastima kao što su industrija, zdravlje i prevencija katastrofa. Konačno, iako ima međunarodno prisustvo, EU ne može lako delovati u globalnoj areni, jer su spoljnopolitičke odluke, između ostalog, ograničene pravilom jednoglasnog glasanja. U takvim okolnostima, pandemija Kovid 19 predstavlja egzistencijalni izazov za EU, jer ugrožava njen identitet i podriva njenu unutrašnju koheziju, te ističe očite razlike u resursima i mogućnostima među članicama, što sveukupno otežava nastup EU kao globalnog aktera. Različiti pristupi država članica prisutni su u brojnim pitanjima, uključujući i stratešku kulturu, a neizvesnost i složena arhitektura evropskog sistema sa unutrašnjiom hijerarhijom sprečava Evropu da politički definiše i sledi svoje interese. ${ }^{12}$

Trenutna ograničenja u spoljnopolitičkom nastupu Unije mogla bi se ublažiti uklanjanjem okvira dezinformacija kao spoljne pretnje, izbegavanjem agresivnog suprotstavljanja drugim geopolitičkim akterima, većim „slušanjem“ drugih aktera

${ }^{10}$ Domenico Valenza, "MUTUALITY ABOVE GEOPOLITICS: Reshuffling EU strategic communication in COVID-19 times", Geopolitics \& Values: what is the real power of the EU?, Institute of European Democrats, Brussels, December 2020, p. 5.

${ }^{11}$ Ibid., p.5.

${ }^{12}$ Detaljnije: Nevena Stanković, „Glavne odrednice spoljne politike Emanuela Makrona", Međunarodna politika, Institut za međunarodnu politiku i privredu, Beograd, 2020, br. 1179-80, str. 51. 
i prevazilaženjem evrocentričnih narativa i praksi. Posledično, suprotno zalaganju aktuelnog VP Žozepa Borelja, korišćenje „jezika moći“ moglo bi dovesti do povećanja razlika (umesto sličnosti) u odnosu na druge međunarodne aktere, i samim tim ugroziti međunarodnu saradnju u trenutku kad nacionalističke tendencije sve više uzimaju maha. U tom smislu, strateška kultura, kao instrument spoljne politike na koji se EU obavezala, nameće se kao najpogodniji instrument za preusmeravanje fokusa sa razmene poruka na „slušanje“ drugih aktera, a u cilju ravnopravnog povezivanja sa svetom.

U javnom diskursu prisutno je mišljenje da će među geopolitičkim akterima tri faktora odrediti ishod takmičenja u odnosu na pandemiju: ko je pružio najadekvatniju i najbržu pomoć, ko će ponuditi najbolje mere oporavka od pandemije i ko je prvi doneo neophodnu vakcinu na tržište i pod kojim uslovima? ${ }^{13}$ lako je mišljenje većine autora da je EU nepripremljena za preokret koji bi mogao uslediti nakon dugotrajne društvene i ekonomske krize izazvane pandemijom, brža koordinacija na polju zdravstvenih pitanja i bolji odnosi sa javnošću, svakako bi poboljšali nastup EU kako u svetlu aktuelnih tako i budućih izazova. Da se bez međusobne solidarnosti i funkcionalnog jedinstvenog tržišta EU ne bi mogla oporaviti, prepoznato je i u programu nemačkog predsedavanja Unijom, koje je započeto u jeku pandemije. ${ }^{14}$

\section{Uloga „,mekih“ normi u spoljnoj politici EU}

Autori su prilično saglasni da u trenutku završetka pandemije Kovid 19 Evropska unija više neće biti ista. Za očekivati je da dalekosežni politički, ekonomski i socijalni efekti pandemije nadjačaju mnoga pravila i mehanizme EU, potencijalno preoblikujući tok evropskih integracija. Pandemija je još jednom istakla slabosti institucija EU, pokazavši da su države članice glavni akteri u upravljanju krizama. U tom smislu, nedostatak solidarnosti među članicama veliki je test za opstanak integracionog projekta. Borba protiv virusa, ali i budućih bezbednosnih i ekonomskih izazova, zahteva od zemalja članica evidentno čvršći

\footnotetext{
${ }^{13}$ Philipp Brugner, Klaus Schuch, "The EU's global response to the COVID-19 crisis with a focus on the Eastern Neighbourhood and Africa", op. cit., pp.2-3.

${ }^{14}$ Detaljnije u: Sena Marić, Strahinja Subotić, Nemačko predsedavanje Savetu EU, CEP pogled, Centar za evropske politike, jul 2020, Beograd.
} 
naučni pragmatizam i odgovornu saradnju na evropskom nivou. Kao rezultat krize evropske ekonomije bi mogle biti značajno restrukturirane, a na osnovu trenutnih procena teško je predvideti na koji način će EU umanjiti svoje gubitke u poređenju sa drugim globalnim akterima. S druge strane, optimistični scenariji polažu nade u normativnu moć EU, instrumente meke moći i meke pravne norme, kao način na koji EU može poboljšati svoj geopolitički položaj i postati treći pol globalnog uticaja, pored SAD i Kine.

U međuvremenu, položaj Kine u Evropi postao je prilično složen. Tokom marta 2020.godine, dok je Kina izlazila iz najgoreg dela pandemije, a nespremna i nejedinstvena Evropa se hvatala u koštac sa pandemijom, činilo se da kineska „diplomatija maski“ niže uspehe, pružajući vitalne zalihe zdravstvene zaštite zemljama EU. Dok se EU se spremala da razvije čvršći odgovor na geopolitičku strategiju Kine, u okviru bliske kinesko-italijanske saradnje načela se ideja o potrebi pokretanja "Puta svile zdravlja“ između Evrope i Kine, zajedno sa inicijativom "Jedan pojas, jedan put". ${ }^{15} \mathrm{~S}$ druge strane, napetost između SAD i Kine eskalirala je krajem 2020. godine kada je Trampova administracija pojačala retoriku protiv Kine, optužujući Peking odgovornim za početno širenje virusa, dok je Peking odgovornost za donošenje virusa u Vuhan prebacio na američku vojsku. Ovakva retorika se nastavila i promenom američke administracije u januaru 2021. godine, nakon održanih predsedničkih izbora. Posledično, za očekivati je da se pomenute tenzije odraze i na EU, zbog ćega će Evropljani biti prisiljeni da se stave na stranu jedne od velikih sila u osetljivim strateškim pitanjima (poput $5 \mathrm{G}$ mreže), te da će biti teško postići unutrašnji konsenzus u EU u odnosu na ovo pitanje.

Sve češća upotreba mekih pravnih alata u institucijama EU otvorila je niz pravnih pitanja - od njihovog statusa u pravnom poretku EU, do njihove pravne vrednosti. Veliki broj autora zastupa mišljenje da je pandemija Kovid 19, ubacivši čitav svet u zdravstvenu krizu, zapravo istakla ranjivost i slabosti demokratskih sistema, kao i potrebu za brzim i temeljnim promenama kako bi se sprečila potpuna erozija demokratskih vrednosti. ${ }^{16} \mathrm{U}$ tom smislu, meka pravna moć se

${ }^{15}$ Gergely Fejérdy, Tamás Levente Molnár, Barnabás Szabó, Gergely Varga, "The Latest Crisis of the European Union: The Political, Economic, and Social Consequences of the New Coronavirus", KKY POLICE BRIEF, No. 55, Institute for Foreign Affairs and Trade, Budapest, 2020, p. 5.

${ }^{16}$ Hava YURTTAGÜL, "THE POWER OF EU SOFT LAW: EU's global leadership in promoting multilateralism through soft law", op. cit., p. 6. 
izdvaja kao atraktivan instrument za upravljanje međunarodnim odnosima, a korišćenje njenih pravnih instrumentata, kao alternativa tvrdim normama i obavezujućim ugovorima, može da deluje prilično stimulativno jer međunarodno ponašanje reguliše na fleksibilan način, pružajući široku marginu delovanja i postavljajući istovremeno temelje međunarodne saradnje. Ovo je relevantno naročito za EU, koja je kao subjekt međunarodnog prava sposobna da deluje na međunarodnoj sceni u granicama svojih nadležnosti, utvrđenih njenim konstitutivnim ugovorima.

Upotreba mekih pravnih instrumenata postala je naročito značajna prilikom definisanja globalnog odgovora EU na pandemiju. U aprilu 2020. godine, manje od mesec dana nakon što je STO kvalifikovala širenje virusa kao pandemiju, Evropska komisija je najavila pokretanje spoljne akcije pod nazivom "Tim Evropa“ (Team Europe). ${ }^{17}$ Paket od približno 15 milijardi evra, namenjen kao podrška partnerskim zemljama u borbi protiv pandemije i njenih posledica, u skladu je sa pristupom promovisanim u Zajedničkom akcionom planu G20. ${ }^{18}$ Evropska komisija je zajedno sa VP za spoljne poslove i bezbednosnu politiku naglasila je da će prioriteti „Tima Evrope“ biti usmereni na „rešavanje neposredne zdravstvene krize i proisteklih humanitarnih potreba, jačanje zdravlja, kao i ublažavanje socioekonomskog uticaja pandemije“. ${ }^{19}$ Sem konkretnih mera, od izuzetne važnosti je i to što je "Tim Evropa“, kao deo kolektivne akcije EU, obuhvatio strategiju saradnje i multilateralizma kojom bi imao za cilj da iskoristi položaj EU kao globalnog aktera za promociju koordiniranog odgovora na krizu. ${ }^{20}$

Važno je istaći da Evropska komisija nije bila jedina koja je pozivala na međunarodnu solidarnost i saradnju tokom krize Kovid 19. lako se nije izričito

${ }^{17}$ Communication on the Global EU response to COVID-19, JOIN(2020) 11 final, Document 52020JC0011 European Commission, Brussels, 8.4.2020.

${ }^{18}$ Extraordinary G20 Leaders' Summit: Statement on COVID-19, G20 Information Centre, 26 March 2020, Internet: http://www.g20.utoronto.ca/2020/2020-g20-statement-0326.html 21/04/2021.

${ }^{19}$ Coronavirus: EU global response to fight the pandemic, European Commission, Press release. 8 April 2020, Internet: https://ec.europa.eu/commission/presscorner/detail/ en/ip_20_604 22/04/2021.

${ }^{20}$ Commissioner Urpilainen: Team Europe with our partners against Covid-19, Statement, European Commission, 28 March 2020, Internet: https://ec.europa.eu/commission /commissioners/2019-202 4/urpilainen/announcements/commissioner-urpilainen-teameurope-our-partners-against-covid-19_en 19/04/2021. 
osvrnuo na inicijativu „Tim Evropa“, Evropski parlament je promovisao sličnu globalnu strategiju EU u svojoj rezoluciji o koordiniranom delovanju EU u borbi protiv pandemije COVID-19 i njenih posledica, ističući da pandemija ne poznaje granice ili ideologije i da je potrebna saradnja i solidarnost čitave međunarodne zajednice.

Imajući u vidu pomenute instrumente i oblike delovanja, čini se da EU pokazuje spremnost da deluje kao katalizator u promociji veće saradnje i međunarodne solidarnosti tokom i nakon pandemije. U tom smislu, prema rečima Haje Jurtagul, presudno će biti da EU poštuje svoje obaveze preuzete usred pandemije i da nastavi da pruža podršku ranjivim zemljama u njihovom nošenju kako sa pandemijom tako i njenim socijalno-ekonomskim posledicama. ${ }^{21} \mathrm{Na}$ tim osnovama su procene dela doktrine da bi upotreba mekih instrumenata moći mogla da ublaži postojeće sukobe i pomogne EU da obezbedi sredstva za ispunjenje svoje ambiciozne globalne misije. Naravno, ovo je moguće samo u onoj meri u kojoj je u skladu sa principima utvrđenim u osnovačkim ugovorima o EU, a procena zakonitosti akata EU je u domenu Evropskog suda pravde. Njegovo posledično proširenje nadležnosti na meko pravo, zahteva od institucija i tela EU da preduzmu dodatne mere predostrožnosti prilikom usvajanja takvih akata kako bi se osigurala usklađenost sa principima utvrđenim u Ugovorima o EU.22 Ove proceduralne mere predostrožnosti pomogle bi da se minimiziraju sukobi nadležnosti, čime bi se ojačao legitimitet spoljne akcije EU obezbeđujući dejstvo mekih pravnih normi EU. Konačno, karakter ovakvog instrumenta spoljne politike EU treba da obezbedi dovoljnu fleksibilnost, kako bi se omogućila potrebna prilagođavanja koja su neminovna u evolutivnoj prirodi sudske prakse u pogledu mekih pravnih normi koje donosi EU.

\section{Multilateralizam i instrumenti normativne moći EU u svetlu pandemije Kovid 19}

Pandemija Kovid 19 stvorila je zahtev za bližom multilateralnom saradnjom. Kombinacija faktora, među kojima su američko-kinesko rivalstvo, evropski

\footnotetext{
${ }^{21}$ Hava YURTTAGÜL, "THE POWER OF EU SOFT LAW: EU's global leadership in promoting multilateralism through soft law", op. cit., p. 15.

22 Ibid., p. 16.
} 
odgovor na pandemiju, kao i potreba za globalnom saradnjom, otvorili su put ponovnom pokretanju multilateralizma. U tom kontekstu, pred EU je zadatak i odgovornost da preuzme ulogu normativnog aktera. Da bi njena normativna snaga dorasla ovom poduhvatu, EU mora da poboljša svoje normativne instrumente, poput regionalnih i strateških partnerstava, istovremeno težeći evropskoj strateškoj autonomiji. Drugim rečima, pored unutrašnjeg jačanja, EU bi trebalo da promoviše dinamičnu i autonomnu spoljnu politiku zasnovanu na svom normativnom identitetu. Posledično, prema rečima Dejvida Fusieka (Dawid Fusiek), od EU se očekuje da postane treći pol uticaja između SAD i Kine i iskoristi svoju normativnu moć da poboljša svoj geopolitički položaj u svetu koji se menja. ${ }^{23}$

Moglo bi se konstatovati da je EU u određenom smislu uspela da popuni vakuum stvoren američko-kineskim rivalstvom, dajući do znanja da poseduje stručnost, alate i mogućnosti da ponese „baklju“ multilateralizma. Međutim, neophodno je da EU instrumentalizuje postojeći zamah i uslove za ponovno oživljavanje multilateralizma, a odlučujući resurs u ovakvim ambicijima leži u njenoj normativnoj moći. Pretpostavka da se na temelju ideja, normi, načela i vrednosti izgrađuje identitet iz koga proizilazi normativna moć, kao i da EU treba da se više rukovodi normativnim načelima u svetskoj politici, prisutna je u stručnoj javnosti. ${ }^{24}$ Uzimajući u obzir činjenicu da se međunarodni poredak suočava sa ozbiljnom krizom usled aktuelne pandemije, EU bi kao ključna normativna sila trebala da dâ primer trećim državama, usmeravajući in ka multilateralizmu. Deo doktrine zastupa mišljenje da EU to može postići formulisanjem multilateralnog poretka koji sadrži evropske norme u svom epicentru. ${ }^{25}$ To bi značilo da u postpandemijskom svetu EU mora da kreira i podržava norme, vrednosti i ideje koje su bile osnova evropskog

${ }^{23}$ Dawid A. FUSIEK, "Towards Normative Power Europe - The EU as a standard-bearer of multilateralism and the role of European norms and values in the post-pandemic geopolitical order", Geopolitics \& Values: what is the real power of the EU?, Institute of European Democrats, Brussels, December 2020, p. 5.

24 Dragana Dabić, „Evropska izbeglička kriza kao izazov teoriji o normativnoj moći Evropske unije", u: Slobodan Janković, Zoran Pavlović, Dragana Dabić (urs), Balkanska migrantska ruta: između politike prava i bezbednosti, Institut za međunarodnu politiku i privredu, Beograd, 2017, str. 56-57.

${ }^{25}$ Dawid A. FUSIEK, "Towards Normative Power Europe - The EU as a standard-bearer of multilateralism and the role of European norms and values in the post-pandemic geopolitical order", op. cit., p. 6. 
projekta i efektivnog multilateralizma. Iz ovoga se može izvesti zaključak da je učešće EU u savremenom multilateralnom poretku istovremeno i funkcionalna nužnost i opšta težnja. Da je posvećenost Unije multilateralizmu formalizovana u korpusu akata i zvaničnom diskursu EU na regionalnom i međunarodnom nivou, svedoče i Evropska bezbednosna strategija iz 2003. godine, Lisabonski ugovor iz 2009. godine, Globalna strategija EU iz 2016. godine, kao neki u nizu dokumenata koji naglašavaju multilateralni pristup.

Nema sumnje da će pandemija u određenom stepenu promeniti i percepciju normativne moci EU. Jedan od najvažnijih izvora međunarodnog uticaja EU leži u njenom statusu ekonomskog partnera i izvora razvojne pomoći. lako ovaj aspekt čini Uniju bitnim igračem na globalnoj sceni, događaji povezani sa korona virusom su donekle potkopali ovakvu reputaciju. ${ }^{26}$ Zabrana izvoza zaštitne zdravstvene opreme EU bila je razumna odluka u pogledu zdravstvene bezbednosti i jačanja solidarnosti među državama članicama, ali je s druge strane praksu nacionalnih vlada uzdigla na nivo EU. Konačno, kako će se očekujući ekonomski pad i fiskalni izazovi koji stoje pred EU negativno odraziti i na njenu spoljnu politiku, poželjno bi bilo da Unija upravo trajanje pandemije iskoristi za reorganizaciju svoje spoljne politike, naročito u pogledu načina na koji definiše, realizuje i postiže svoje ciljeve. Međutim, upitno je da li je ovakva vrsta institucionalne reforme moguća, u situaciji kada veliki broj država članica spoljnu politiku još uvek vidi kao oblast isključivog nacionalnog domena i insistira na principu jednoglasnosti u Savetu spoljnih poslova, gde se konzervativni i liberalni koncepti često konfontiraju. S obzirom na to da EU nema težnju da postane tzv. tvrda sila, a meka moć je često u praksi nedovoljna, autor Stefan Dreksler (Stefan Drexller) nudi koncept progresivnog realizma, kao potencijalno korisnog za novi spoljnopolitički pristup EU. Ovaj concept, prema njegovim rečima, podrazumeva kombinaciju merljivih ekonomskih i diplomatskih uspeha zasnovanih na (progresivnim) vrednostima, kao neku vrstu razumnog balansa između „,sebičnosti i altruizma“, za oblasti poput kontrole naoružanja, humanitarnih intervencija, trgovine ili obrazovanja. ${ }^{27}$ Svakako, predstojeća neizbežna debata

${ }^{26}$ Gergely Fejérdy, Tamás Levente Molnár, Barnabás Szabó, Gergely Varga, "The Latest Crisis of the European Union: The Political, Economic, and Social Consequences of the New Coronavirus", op. cit., pp. 13-14.

${ }^{27}$ Stefan Drexler, "Progressive realism as a model for Europe's new foreign policy", Geopolitics \& Values: what is the real power of the EU?, Institute of European Democrats, Brussels, December 2020, pp. 5-6. 
o budućnosti EU nema smisla bez suštinske reforme njenih spoljnopolitičkih ciljeva. Ovakva reforma bi značila i preusmeravanje multilateralnog fokusa EU na teme gde sve strane koje učestvuju mogu da profitiraju od saradnje.

Velike globalne krize dokazale su da efikasan i održiv multilateralni poredak nije moguć bez normativnih osnova i aktivnog pristupa Evropske unije. Zbog toga Unija, u svom zvaničnom diskursu, poslednjih godina sve glasnije govori o značaju multilateralizma. Prema uverenju naučne zajednice, izbijanje korona virusa i postojeća ekonomska i politička situacija stvorili su uslove za EU ne samo da ponovo pokrene multilateralizam, već i da se nametne kao njegov najpouzdaniji promoter i podrška. Nakon izbijanja pandemije, retorika i jednostane odluke Kine i SAD dodatno su ojačale ovu percepciju. Suprotno, Unija je upravo kroz multilateralizam, podsticala na deeskalaciju svetske zdravstvene krize, pružajući tehničku i materijalnu podršku radu međunarodnih organizacija, ostavivši na ovaj način „, pozitivan utisak" na međunarodnu zajednicu. ${ }^{28}$

Nesumnjivo da je Unija ispoljila kapacitet da dâ zamah multilateralizmu tokom prethodnih godina, uživajući ulogu posrednika na međunarodnim forumima i dajući doprinos usvajanju bitnih sporazuma. ${ }^{29}$ Primer za ovo je Pariški sporazum iz 2015. godine, kome je prethodila saradanja Nemačke, Francuske i ostalih članica sa SAD, kao i privlačenje Rusije i Kine čime se osiguralo usvajanje završnog dokumenta. ${ }^{30}$ Upravljanje transnacionalnim krizama zahteva od EU formulisanje brzog odgovora na međunarodnom nivou. EU je demonstrirala da može voditi multilateralizam tokom krize izazavane pandemijom Kovid 19 i njenim posledicama, tako što je instrumentalizovala multilateralne organizacije (UN, G7, G20, SZO, STO) kao platforme za komunikaciju i formulisanje rešenja. Osim toga, finansirala je većinu globalnih inicijativa i pružila finansijsku pomoć svojim regionalnim partnerima u kontekstu svog globalnog odgovora na pandemiju. ${ }^{31}$

\footnotetext{
${ }^{28}$ Dawid A. FUSIEK, "Towards Normative Power Europe - The EU as a standard-bearer of multilateralism and the role of European norms and values in the post-pandemic geopolitical order", op. cit., p. 7.

${ }^{29}$ Indikativno je da je evropski zvaničnik u Njujorku u okviru UN procenio da države članice EU zauzimaju mesto sazivanja ili predsedavanja u otprilike četiri petine pregovaračkog procesa UN.

${ }^{30}$ Dawid A. FUSIEK, "Towards Normative Power Europe - The EU as a standard-bearer of multilateralism and the role of European norms and values in the post-pandemic geopolitical order", op. cit., p. 8.

${ }^{31} \mathrm{Ibid}$.
} 
Da bi uspešno upotrebila svoju normativnu moć, Unija ima na raspolaganju set instrumenata. Među njima su najznačajniji: spontana difuzija, odnosno mogućnost da se norme šire prirodnim putem i van granica EU bez direktnog angažovanja same Unije, zatim upotreba komunikacionih strategija odnosno informatička aktivnost, proceduralna aktivnost tj. institucionalizacija odnosa sa trećim zemljama, prisustvo EU u trećim zemljama, kulturna difuzija kao proces učenja evropskih vrednosti od strane trećih država i slično. U kontekstu toga, pravna posvećenost EU svojim normama koje se odnose na ljudska prava, nediskriminaciju i multilateralizam su i manifestacija lojalnosti i garancija njenog modus operandi usmerenog ka trećim državama. Odličan primer za to je Globalna strategija Unije iz 2016.godine, gde se termin demokratija pominje dvadeset puta, mir šezdeset, a ljudska prava trideset. ${ }^{32}$ Konačno, prema Fusieku, najistaknutije sredstvo normativne moći EU leži u njenim proceduralnim aktivnostima i prenosu povlastica na treće države, s obzirom na to da je Evropa najveći svetski izvoznik roba i usluga. Svoju ekonomsku moć EU koristi za bilateralna ili regionalna partnerstva. Njena globalna pozicija je poslednjih godina ojačana uspostavljanjem veza sa nizom međunarodnih aktera (od Brazila i Japana do zemalja Kariba i Atlantika), kao i velikim brojem multilateralnih inicijativa koje su institucionalizovale politički dijalog i odnose sa regionalnim državama. lako u različitim stepenima, EU vodi operativnu strukturnu spoljnu politiku prema zemljama Centralne i Istočne Evrope, Balkana, mediteranske oblasti, pojedinim zemljama Zajednice nezavisnih država i u manjoj meri prema podsaharskoj Africi. No, za potpuno sagledavanje politike i strategije Unije prema konkretnim zemljama ili regionima, potrebna je detaljna analiza celine njenih aktivnosti i politika u odnosu na datu državu. ${ }^{33}$ Zaključno, koristeći svoje institucije, finansijska sredstva i sporazume, EU je u stanju da svoje norme dobrovoljno i efikasno implementira u brojne države izvan Unije.

Da evropski lideri i diplomate aktivno promovišu koalicije i poslaničke klubova u znak podrške multilateralizmu, svedoči i nemačka inicijativa tzv. Saveza multilateralizma, koja je usmerena na međunarodni poredak zasnovan na

32 Shared Vision, Common Action: A Stronger Europe - A Global Strategy for the European Union's Foreign And Security Policy, European Commision, June 2013, Internet: https://eeas.europa.eu/archives/docs/top_stories/pdf/eugs_review_web.pdf_

${ }^{33}$ Nevena Stanković, „Spoljna politika Evropske unije u teorijskom konceptu strukturne spoljne politike“, Nacionalni interes, Institut za političke studije, Vol. 37, br. 1, Beograd, 2020, str. 15. 
pravilima i ključne instrumente međunarodne saradnje. ${ }^{34}$ Ne treba zanemariti ni zalaganja EU za saradnju u novim oblastima politike, kao što su sajber bezbednost, zdravlje ili klimatske promene, u poslednjim godinama. Posmatrano iz ove perspektive, čini se da postpandemijski multilateralni poredak ostavlja širi prostor Uniji, da kombinacijom stručnosti i globalne privlačnosti izdvoji sebe od ostalih aktera na međunarodnom planu.

\section{Budućnost EU kao normativnog aktera u međunarodnom poretku}

Ubrzo nakon pojave, koncept normativne moći izgubio je svoju popularnost. U poslednje dve decenije niz unutrašnjih kriza, sa kojima se EU suočila, negativno su uticale na njen normativni imidž i identitet. Trenutne globalne okolnosti vratile su ovaj koncept u središte pažnje nauke, ali i kreatora svetske politike. Zapravo, nedostatak adekvatne moći koja pokreće multilateralizam stvorio je prazninu koju bi mogao popuniti odgovarajući normativni akter, u ovom slučaju EU. Prema rečima Fusieka, da bi iskoristila ovu šansu Unija ne treba da sledi zastarele i neefikasne prakse poput trke u naoružanju, već bi trebalo da ulaže u svoju normativnu moć i vrši pozitivan uticaj na preostale treće države u vreme kriza. ${ }^{35} \mathrm{Na}$ taj način Unija postiže dvostruki rezultat - a to je usmeravanje drugih država ka multilateralnoj saradnji i nametanje sebe kao vodeće normativne sile u ovom procesu.

$\mathrm{Na}$ istim osnovama ostaje i Jan Meners (Ian Manners) kada tvrdi da, suprotno ostalim velikim silama, EU ne oblikuje toliko međunarodni sistem uz upotrebu klasičnih instrumenata tvrde moći, već su njena nastojanja više usmerena na privlačnost ideja, standarda i vrednosti koje pokreću projekat evropskih integracija. ${ }^{36}$ Te ideje uključuju mir, slobodu, demokratiju, nadnacionalnu vladavinu zakona i ljudska prava, socijalnu solidarnost, antidiskriminaciju, održivi

\footnotetext{
${ }^{34}$ Marko Savković, Kome će pripasti budućnost? Poziv na obnovu multilateralizma, 10.oktobar 2019, Internet: https://bfpe.org/u-fokusu/spoljna-politika-i-bezbednostfokus/kome-ce-pripasti-buducnost-poziv-na-obnovu-multilateralizma/22/04/2021.

${ }^{35}$ Dawid A. FUSIEK, "Towards Normative Power Europe - The EU as a standard-bearer of multilateralism and the role of European norms and values in the post-pandemic geopolitical order", op. cit., p. 9.

${ }^{36}$ Ian Manners, "Normative Power Europe: A Contradiction in Terms?", Journal of common market studies(JCMS), Vol. 40, No. 2, June 2002, pp. 239-240.
} 
razvoj i dobro upravljanje. lako su ove norme manifestacija identiteta, vrednosti i ideja EU, one je takođe preusmeravaju da deluje na normativni način, prvenstveno zbog svoje pravne prirode. To zapravo znači da većina ovih principa ne predstavlja puku retoriku, već se radi o pravno obavezujućim normama prisutnim u izvorima prava i zvaničnim dokumentima EU. ${ }^{37}$

Mišljenje da iskušenje EU u pogledu korišćenja jezika moći na kraju može samo povećati razlike umesto sličnosti, ugrozivši time međunarodnu saradnju u veoma osetljivom trenutku, nesumljivo je prisutno u delu naučne javnosti. $U$ skladu s tim, geopolitika multilateralizma može biti prvi korak ka prepoznavanju raznolikosti sveta izvan granica EU, a činjenica je da se međunarodni akteri vode različitim normama i vrednostima. ${ }^{38} \mathrm{EU}$ svakako poseduje alate za reformu multilateralne strukture, ali ovaj poduhvat treba da se zasniva pre svega na njenoj normativnoj moći. Iz tog razloga, možemo konstatovati da njen budući modus operandi traba da se oslanja na dvostruki pristup: negovanje multilateralizma $s$ jedne, i povećavanje normativne moći s druge strane. Pandemija korona virusa predstavlja dobru priliku da EU uz ambiciozne politike usvoji i konkretne mere, kako bi postigla oba zadatka. U ovakvim nastojanjima, čini se presudnom istajnost i doslednost Unije da poštuje svoje obaveze preuzete usled Kovid pandemije, kao i doslednost i kontinuitet u pružanju podrške ranjivim zemljama u njihovoj borbi tokom trajanja zdravstvene krize i suočavanja sa njenim socijalno-ekonomskim posledicama. ${ }^{39}$

Na temelju prethodnih iskustava, čini se da bi dobra polazna osnova za veće korišćenje kapaciteta normativne moći bila upravo saradnja sa istomišljenicima i drugim demokratskim snagama na međunarodnoj sceni. ${ }^{40}$ Zajednički sistemi vrednosti i ideja čine mnogo lakšu i efikasniju saradnju u oblasti visoke politike. Drugim rečima, EU bi trebala da postane pol privlačenja i pomoći u formulisanju

${ }^{37}$ O vrednostima na kojima je Unija zasnovamna pogledati: Član 2 Ugovora o EU, Milutin Janjević, Konsolidovani Ugovor o Evropskoj uniji: Od Rima do Lisabona, JP Službeni glasnik, Beograd, 2009, str. 29.

${ }^{38}$ Domenico Valenza, "MUTUALITY ABOVE GEOPOLITICS: Reshuffling EU strategic communication in COVID-19 times", op. cit., p. 13.

${ }^{39}$ Hava YURTTAGÜL, "THE POWER OF EU SOFT LAW: EU's global leadership in promoting multilateralism through soft law", op. cit., p. 15.

40 Dawid A. FUSIEK, "Towards Normative Power Europe - The EU as a standard-bearer of multilateralism and the role of European norms and values in the post-pandemic geopolitical order", op. cit., p. 14. 
pojačane saradnje, bilo institucionalno, poput Saveza za multilateralizam, bilo putem bilateralnih veza. Shodno tome, tekuća situacija prouzrokovana pandemijom može pomoći Uniji da sačuva trenutni zamah, obezbeđujući dalju institucionalizaciju svojih odnosa sa trećim državama. Primećuje se da je izbijanje korona virusa rezultiralo formulisanjem bližih veza sa zemljama poput Japana, Indije i Republike Koreje. S druge strane, u pogledu bilateralnih odnosa sa sistemskim „rivalima“ na međunarodnoj sceni, EU bi trebalo da sledi adaptivnu i prilagođenu diplomatiju. ${ }^{41}$

Vodeći se istim principom, Unija bi trebalo da prilagodi i modernizuje svoj regionalni pristup i nastavi da razvija partnerstva sa regionalnim akterima. Izbijanje korona virusa i polarizacija međunarodnog sistema pogoršali su postojeća pitanja u nekoliko regiona i stvorili mogućnosti za za širenja normativne moći EU. U poređenju sa drugim velikim silama, EU ima jak normativni i ekonomski uticaj u region, pa se očekuje da ojača postojeće veze i iskoristi in za jačanje postojećeg normativnog uticaja. Jednostavan način da se to postigne je formulisanje trgovinskih sporazuma i obezbeđivanje paketa finansijske pomoći. ${ }^{42}$ Povrh toga, EU bi trebalo da nastavi da održava svoje regionalne projekte, poput Evropske politike susedstva, i drugih važnih regionalnih institucija (OEBS i ASEAN), ali da istovremeno traži načine da ih instrumentalizuje putem normativne moći, kako bi služili njenim interesima. Tokom poslednjih decenija, regionalna partnerstva, susedske politike i opšte regionalne multilateralne inicijative EU pokazale su se kao odlični kanali političkog dijaloga, kao i normativne i kulturne difuzije. U tom kontekstu od Unije se očekuje da pojača svoje prisustvo u trećim državama i pomogne u rešavanju regionalnih pitanja, preuzimajući značajnije time ulogu globalnog aktera.

Ipak, deo autora upozorava da EU mora strogo voditi računa da ne pređe granicu između saradnje i "oblika neokolonijalizma" u projektima koje finansira. Drugim rečima, ako bi spoljna politika EU zanemarila postojeće duboko nepoverenje i koristila civilizacijski univerzalni jezik, čak i najneutralniji

${ }^{41}$ Ovo podrazumeva da uprkos različitim pogledima na pojedina pitanja, poput ljudskih prava, odbrane i slično, saradnja sa drugim relevantnim akterima svetske politike je nužna, očekivana i podrazumevana radi interesa svih strana.

42 Upravo je to i bilo obrazloženje EU za isporuku 15,6 milijardi u kontekstu programa „Globalni odgovor EU u borbi protiv pandemije“, koji je imao za cilj rešavanje kratkoročnih potreba EU partnera i kao dugoročniji strukturni uticaj na društva i ekonomiju u tim zemljama. 
pokušaj mogao bi se shvatiti kao subverzivan potez u pravcu neokolonijalizma, imajući u vidu da negativna percepcija bivših evropskih vladara ostaje široko rasprostranjena u trećim zemljama. Zaključno, uključivanje partnera iz trećih država u koncepciju i dizajn kulturnih projekata od samog početka, kao i zajedničko stvaranje novih projekata, može poslužiti kao temelj dubokih i trajnih veza. ${ }^{43}$

\section{Zaključak}

Pandemija virusa Kovid 19 iznela je na videlo krhkost globalne umreženosti, globalnih sistema upravljanja i lanaca snabdevanja, međunarodne povezanosti i pokretljivosti. Ipak, sa sve većim širenjem obuhvata vakcinacije polako se uobličavaju stavovi o doglednom prevazilaženju akutne faze krize.

U pogledu spoljnopolitičke uloge EU, pandemija je pokazala da se kao ključna izdvajaju pitanja mere u kojoj Unija deluje na međunarodnoj sceni, i mere u kojoj to čine države članice; pitanje mogućnosti konceptualnog odvajanja ova dva nivoa i pitanje najvažnijih instrumenata njenog spoljnopolitičkog delovanja, u svetlu aktuelnih izazova. Kao posebno se izdvaja pitanje mogućnosti Unije da, kao globalni akter, preuzme značajniju ulogu u promovisanju multilateralizma, kao zamemarenog koncepta svetske politike. Pandemija Kovid 19 potvrdila je narativ urušenog multilaterarnog sistema, koji se nakon decenija intenzivne globalizacije i integracije suočio sa ozbiljnom krizom.

Prethodna analiza ukazuje koji su uslovi, ali i mogući načini, za ponovno pokretanje multilateralizma u EU. Korišćenje mekih pravnih instrumentata, nasuprot tvrdim normama i zakonima sa obavezujućim dejstvom, atraktivno je na polju međunarodnih odnosa jer reguliše međunarodno ponašanje na fleksibilan način, pružajući široku marginu delovanja, istovremeno postavljajući temelje međunarodne saradnje. Stvorivši zahtev za bližom multilateralnom saradnjom, uz nužnost globalne saradnje, postojeća zdravstvena kriza otvorila je put ponovnom pokretanju multilateralizma.

lako se u prošlosti koncept normativne moći zanemarivao, trenutne egzistencijalne i operativne krize multilateralizma vratile su interes za njegovo

\footnotetext{
${ }^{43}$ Domenico Valenza, "MUTUALITY ABOVE GEOPOLITICS: Reshuffling EU strategic communication in COVID-19 times"? op. cit., p. 11.
} 
oživljavanje, kako u teoriji tako u praksi. Kombinacija fenomena pandemije i rasta evropskog uticaja trasirala je put Uniji da dodatno poveća svoj normativni uticaj na međunarodnom i regionalnom nivou. Ako se ovi uslovi budu pravilno iskoristili, normativna moć bi mogla postati važno oruđe evropske spoljne politike i mogla bi se pokazati vitalnom u zadatku ponovnog pokretanja multilateralizma. Iz tog razloga EU treba da nastavi da ulaže u unapređenje i širenje svoje normativne moći. Stavljanjem svojih normi, ideja i vrednosti u epicentar novog međunarodnog poretka, EU je stanju da povrati poverenje u ideju evropskog projekta, pozicionirajući sebe kao kredibilnog međunarodnog aktera u postpandemijskom svetu.

\section{Literatura}

Brugner, Philipp, Schuch, Klaus, "The EU's global response to the COVID-19 crisis with a focus on the Eastern Neighbourhood and Africa", Österreichische Gesellschaft für Europapolitik, ÖGfE Policy Brief, No.13, Vienna, 2020.

Communication on the Global EU response to Covid 19, JOIN(2020) 11 final, Document 52020JC0011, European Commission, Brussels, 8.4.2020.

Dabić, Dragana, „Evropska izbeglička kriza kao izazov teoriji o normativnoj moći Evropske unije" u: Slobodan Janković, Zoran Pavlović, Dragana Dabić (urs), Balkanska migrantska ruta: između politike prava i bezbednosti, Institut za međunarodnu politiku i privredu, Beograd, 2017.

Drexler, Stefan, „Progressive realism as a model for Europe's new foreign policy“, Geopolitics \& Values: what is the real power of the EU?, Institute of European Democrats, Brussels, December 2020.

Emiliani, Tommaso, "How Relevant? The EU's 'Geopolitical' Commission and the Response to the Covid-19 Pandemic", CEPOB - College of Europe Policy Brief, No. 4, April 2020.

Fejérdy, Gergely, Levente Molnár, Tamás, Szabó, Barnabás, Varga, Gergely, "The Latest Crisis of the European Union: The Political, Economic, and Social Consequences of the New Coronavirus", KKY POLICE BRIEF, No.55, Institute for Foreign Affairs and Trade, Budapest, 2020.

FUSIEK A., Dawid, "Towards Normative Power Europe - The EU as a standardbearer of multilateralism and the role of European norms and values in the 
post-pandemic geopolitical order", Geopolitics \& Values: what is the real power of the EU? Institute of European Democrats, Brussels, December 2020. Janjević, Milutin, Konsolidovani ugovor o Evropskoj uniji-od Rima do Lisabona, JP Službeni glasnik, Beograd, 2008.

Jerzy Bronert, Mikolaj, "CAN THE COVID CRISIS LEAD TO LEGITIMIZATION OF EUROPEAN UNION'S FOREIGN POLICIES? Lessons from Belarus", Geopolitics \& Values: what is the real power of the EU? Institute of European Democrats, Brussels, December 2020.

Manners, Ian, "Normative Power Europe a Contradiction in Terms?", Journal of common market studies, Vol. 40, No. 2, June 2002.

Marić, Sena, Subotić, Strahinja, Nemačko predsedavanje Savetu EU, CEP pogled, Centar za evropske politike, jul 2020, Beograd.

Stanković, Nevena, „Glavne odrednice spoljne politike Emanuela Makrona“, Međunarodna politika, Institut za međunarodnu politiku i privredu, Beograd, 2020, br. 1179-80.

Stanković, Nevena, „Spoljna politika Evropske unije u teorijskom konceptu strukturne spoljne politike", Nacionalni interes, Institut za političke studije, Vol. 37, br. 1, Beograd, 2020.

Shared Vision, Common Action: A Stronger Europe - A Global Strategy for the European Union's Foreign And Security Policy, European Commission, June 2013.

Valenza, Domenico, „MUTUALITY ABOVE GEOPOLITICS : Reshuffling EU strategic communication in COVID-19 times",Geopolitics \& Values: what is the real power of the EU?", Institute of European Democrats, Brussels, December 2020.

Yapar, Hakan, "Solidarity within the Union in the face of Covid-19: affirmation or shattering of hopes for EU's Relevance", Department of Political Science and International Relations, Bahcesehir University The TEPSA Student Contest 2020, April 5, 2020.

YURTTAGÜL, Hava, "THE POWER OF EU SOFT LAW: EU's global leadership in promoting multilateralism through soft law", Geopolitics \& Values: what is the real power of the EU? Institute of European Democrats, Brussels, December 2020. 


\title{
NORMATIVE POWER AS AN ASPECT OF THE FOREIGN POLICY OF THE EUROPEAN UNION IN THE CONTEXT OF THE COVID- 19 PANDEMIC
}

\begin{abstract}
The outbreak of the COVID-19 pandemic is the latest in the series of challenges that the European Union has faced over the past decade, considering the project of European integration, both internally and externally. It turned out that despite the international presence, the EU cannot act unique on the global stage, which is partially caused by the rule of unanimous voting in the field of its foreign policy. The initial lack of internal solidarity and coordination within its members disqualified the Union as a credible geopolitical actor, capable of an adequate response to the crisis.

On the other hand, the pandemic provided the Union with an opportunity to finally create its geopolitical profile and strengthen its position in a changing world. In this context, the pandemic has created a demand for closer multilateral cooperation. Combined factors, such as the US-China competition, the European response to the pandemic, and the need for global cooperation, have traced the path for the relaunch of multilateralism in Europe. The combination of these phenomena- the pandemic and the growth of European influence- brought a chance for the Union to increase further its normative influence at the international and regional levels.
\end{abstract}

The main hypothesis in this paper is that the EU should use its normative power to enhance its geopolitical position, thus becoming the third pole of influence between the US and China. In addition to internal cohesion, the EU should promote a dynamic and autonomous foreign policy based on its normative identity. This requires that the EU improves its normative instruments, such as regional and strategic partnerships while striving for European strategic autonomy.

Analyzing the existing weaknesses, but also new possibilities in the EU's foreign policy approach, which relies on new multilateralism, the paper examines the possibilities of future cooperation of the Union with the rest of the world in light of new challenges arising from the COVID-19 pandemic.

Keywords: EU, pandemic, COVID-19, multilateralism, foreign policy, normative power. 